\title{
Understanding Climate Change Adaptation Issues in Nepal
}

Ngamindra Dahal ${ }^{1}$

\begin{abstract}
Nepal has observed trend of annual increase in temperature per decade by $0.41^{\circ} \mathrm{C}$ which is much higher than global average. Climate change is relatively new challenge of global scale but have strong local effects. The evidences of the global warming and climate change are more prominent on the Himalayan region of the globe with melting of ice, glacier retreat, and worst of all the incidence of glacial lake outburst floods with the aftermath falling directly on the ecosystem. The most critical areas are the resource poor developing countries like Nepal which are first to face this calamity yet helpless to implement any concrete ideas still. Nepal has to develop its mechanism to disseminate information regarding climate change and its rational use in planning and implementing policy processes with simultaneous approach on the research to follow the trend of climate change. Thus, this paper focuses on Nepal strategies to cope with challenges of climate change keeping in view the shifting focus of global climate policy.
\end{abstract}

Key Words: Climate change, Global warming, Glacial retreat, Depleting ice, Ecosystem

\section{Introduction}

Effects of global warming encompass all vital systems supporting world populations. Human health, agriculture, forest, water resources and biodiversity will suffer at different scales depending on local conditions. Assessing local impacts of global warming is essential to plan coping strategy with emerging uncertainties. Gathering evidences of climate change impacts on any local pattern is a challenge as it involves complex task of building long-term data, analysis of the data and interdisciplinary investigations. It is further difficult task in a country like Nepal where climatic database is comparatively weak in terms of network coverage, duration and quality.

In this paper, emerging trends and challenges of climate change impacts are discussed in the context of shifting global policy focus. and growing vulnerability of people in Nepal. Some remedial options and priority actions are also discussed.

\section{Shifting Focus of Global Climate Policy}

Current global debates on climate change focus on specific 'actions' to adapt or mitigate the unintended impacts than gathering 'evidences' to show that climate change is happening. This is a major shift from the debate whether climate change is real threat or not. Nowadays the dialogues are mainly about the economy of mitigation and adaptation measures to cope with

\footnotetext{
$\overline{1}$ National Trust for Nature Conservation, PO Box 3712, Kathmandu, Nepal, ndahal@ntnc.org.np
} 
the emerging threats of global scale. There is no doubt among scientists and researchers that earth is getting warmer due to greenhouse effects leading to unintended changes in climatic patterns. Enormous evidences support that climate change impacts will be wider from global to local scale, deeper and long term. However there is no breakthrough on global policy dialogues regarding who and how to move ahead to cope with the unintended consequences of climate change. Major consequences will be the drought, flood and landslides that may occur overlapping with those usual one but in higher frequency and intensity.

Recent IPCC report (2007) ${ }^{2}$ has hinted of more devastating effects of climate change on global environment than previous estimate. In essence, the report highlights two implications. First, concentration of green house gases in our atmosphere has already crossed the acceptable limit, thus, triggering irreversible changes in the earth's weather pattern. It implies that adaptation measures to cope with the unintended consequences of climate change effects are imperative. Second, there is no alternative of cutting down high emission rates of green house gases through strong mitigation measures at the earliest possible time frame. The report also warns that 'no action' is no more an option to both industrialized and developing nations. It is, therefore, important to analyse Nepal's status of climate change impacts and policy measures adopted for coping with the emerging challenges.

\section{Local Impacts of Global Warming}

Nepal's Initial National Communication Report on Climate Change to UNFCCC mentions increased seasonal and annual air temperature over the last few decades. Observed annual trend of temperature rise per decade is $0.41^{\circ} \mathrm{C}$ while seasonal rising trend for temperature during pre-monsoon, monsoon and winter periods are $0.43^{\circ} \mathrm{C}, 0.43^{\circ} \mathrm{C}$ and $0.37^{\circ} \mathrm{C}$ per decade respectively (MOPE 2004). This is much higher than of global average.

Visible changes such as glacier retreat in the Himalaya are well monitored; therefore, it is possible to project future scenarios of water discharge in snow-fed rivers. Melting snow and glaciers is a direct impact of climate change. In the Himalayan glaciers, the trend of depleting

\footnotetext{
Some findings of the report are -

- Changes in the land surface (vegetation, soils, water) resulting from human activities can affect regional climate through shifts in radiation, cloudiness and surface temperature.

- Changes in vegetation cover affect surface energy and water balances at the regional scale, from boreal to tropical forests. Models indicate increased boreal forest reduces the effects of snow albedo and causes regional warming. Observations and models of tropical forests also show effects of changing surface energy and water balance.

- The impact of land use change on the energy and water balance may be very significant for climate at regional scales over time periods of decades or longer.

- Atmospheric carbon dioxide $\left(\mathrm{CO}_{2}\right)$ concentration has continued to increase and is now almost 100 ppm above its pre-industrial level. The annual mean $\mathrm{CO}_{2}$ growth rate was significantly higher for the period from 2000 to 2005 $(4.1 \pm 0.1 \mathrm{GtC} \mathrm{yr}-1)$ than it was in the $1990 \mathrm{~s}(3.2 \pm 0.1 \mathrm{GtC} \mathrm{yr}-1)$.

- Carbon dioxide cycles between the atmosphere, oceans and land biosphere. Its removal from the atmosphere involves a range of processes with different time scales. About $50 \%$ of a $\mathrm{CO}_{2}$ increase will be removed from the atmosphere within 30 years, and a further $30 \%$ will be removed within a few centuries. The remaining $20 \%$ may stay in the atmosphere for many thousands of years.

- Future climate change may cause significant air quality degradation by changing the dispersion rate of pollutants, the chemical environment for ozone and aerosol generation and the strength of emissions from the biosphere, fires and dust. The sign and magnitude of these effects are highly uncertain and will vary regionally.
} 
ice deposits can be observed spectacularly. In average the glaciers are retreating at the rate of 2 meters per year. The rate of glacial retreat reached up to $1.8 \mathrm{~m}$ per year in the $1970 \mathrm{~s}$ and $2.4 \mathrm{~m}$ per year in the $1980 \mathrm{~s}$. As a result of fast glacial melt, new glacial lakes have formed and those already existing have grown rapidly. Visible changes such as glacier retreat in the Himalaya are well monitored; therefore, it is possible to project future scenarios of water discharge in snow-fed rivers. This alarming highland trend threatens downstream communities and the environment due to the increased risk of glacial lake outburst floods. The occasional bursting of glacial lakes in the past has seriously damaged the lives and livelihoods of mountain communities. Such threats operate in conjunction with other changes to the patterns of river flow, spring water recharge, precipitation and vegetation types expected as a result of global warming in the Himalayas.

Though rise in mean temperatures over the last few decades is a strong evidence of climate change, it is not simple to measure impacts on various sectors. Effects of temperature rise are imbedded in ongoing complex dynamic processes such as weather, season, vegetation and hydrologic patterns.

\section{Impacts on Ecosystem}

Though it is widely speculated that climate change will add a new stress to ecosystems and socioeconomic systems already affected by poverty, natural resources depletion and unsustainable management practices, very little is known the exact nature. Possibility of wider gaps in protected area management is one of the projected impacts of climate change in ecosystem management. The nature of impacts however is complex because of each ecosystem component is interlinked. It is also very specific to local context.

Some key factors include shift of species range, ecosystem resilience and connectivity, topography, extinction risk, sea-level change, landscape ecology, montane geography \& disturbance regime. This type of projections has clear implications to Nepal as well for her one of the richest bio-diversity and unique geographical position in the world. With 5833 species of flowering plants, including about 248 species of endemic plant and 700 species of medicinal plants, Nepal's landmass is home to 26 species of mammals, 9 species of birds and 3 species of reptiles that are declared endangered and are being protected by Nepalese laws (MOPE, 2001).

\section{Considering Options for Climate Change Adaptation}

Earth climate has already exhibited clear signs of unintended changes in weather patterns, both adaptation and mitigation measures are equally important to avert the looming crisis over human civilization. Climate change is relatively new challenge of global scale but have strong local effects. Uncertainty of climate change impacts is a serious threat. It involves costs for research, planning and implementing adaptation measures. Irony is that the more vulnerable one is already in stress due to resource crunch and has no capacity to implement measures without external support. 
Nepal is highly vulnerable to climate change for two main reasons. First, higher number of extreme climatic incidents is likely to occur resulting in more loss of lives, properties and source of livelihoods. Second, already facing resource crisis, Nepal is not in position to afford huge costs of implementing adaptation measures, thus, very likely to remain trapped in vicious cycle of poverty. Indeed, Nepal has already been suffering from climate change-led impacts such as depletion of snow cover, glacier retreat and glacial lake out-burst flood. At community level, problems like erratic rainfall patterns, water hazards, water shortage and vector borne diseases are reported to be growing.

Understanding the change pattern of weather, hydrology, water, vegetation, agriculture and extreme weather events is essential to employ adaptation measures. Adaptation to adverse impacts of climate change, however, is not simple task for weather being a very dynamic process having complex interactions with diverse earth surfaces. Assessment of vulnerability and addressing of context specific problems is vital for prioritizing of adaptation measures.

Growing concern of developed countries on climate change related problems have triggered interests of planners and researchers to focus their research activities on the potential challenges and problems through multiple disciplines. Nepal, being a least developed country, can learn from others to replicate good practices through the access of global climate funds for sustainable technologies.

\section{Building Capacity to Tap Adaptation Funds}

Opportunity lies in capitalizing Nepal's rich biodiversity, forests, fresh water and scenic landscape in its natural form. Schemes may be developed value adding to the local services. In future, study should focus on specific impacts of climate change on behavior of wildlife species, range of habitat and food, migration and incidents of epidemic diseases among others. This type of information is vital for planning wildlife and biodiversity conservation activities and implementing adaptive measures to cope with the challenges. Immense uncertainties associated with complex effects of climate change on all aspects of biosphere need to be recognized.

At micro level, building capacity of local communities is a key approach to cope with unintended effects of climate change. Capacity building plan should aim to enhance resilience power that is the major component of 'climate change adaptation' policy. Developing and maintaining a good stock of forest cover, wood stocks and food; building series of small ponds to trap rainwater, diversity of income sources, insurance of properties or business schemes, good governance practices, and levels of education, awareness and leadership capacity are some of the examples of adaptation measures applicable to Nepali rural communities.

The Himalayan glaciers serve as a barometer for monitoring effects of global warming. Because of the unique geographic diversity within a short span, Nepal can attract the researchers to conduct climate change related research activities while allowing Nepali researchers and planners to play the active roles. Outcomes of the researches could be useful to plan adaptation and mitigation activities. 


\section{Opportunity of making environmental services payable to local community}

A study of NTNC (2006) shows Nepal's community forestry as a huge source of carbon sequestration if it is recognized as an eligible sector for carbon trade. Importance of the study lies on the fact that rural communities of developing nations have a crucial role to restore and manage local forests. Like any other forests, these are the source of numerous environmental services including carbon sequestration, reduced or avoided deforestation/ degradation, watershed protection and biodiversity conservation. Thus, prospect of harvesting Nepal's community forests as a potential source of carbon sequestration is high; but is not free from underlying challenges and complexities. Costs of monitoring carbon stocks in remote forests by trained technicians, methodological problems, leakage possibility and managing risks of fires as well as quality of carbon credits in comparison of other sectors are the major issues to be tackled. Realizing the benefits, however, require concerted efforts and lobbying at international policy dialogues.

Though challenging, already a significant progress has been made to achieve the goal of securing climate change funds to the community managed forests for carbon sequestration service. The financial incentive if received to the rural community serves critically important role for biodiversity conservation, promotion of clean energy technologies, and poverty reduction. With 2 tons per ha per year growth, the $\mathrm{CF}$ sector can generates 2.4 million tons of carbon in a year. Current international market price of 1 ton carbon ranges from $\$ 5$ to \$20. With \$ 5 per ton, there is a prospect of Nepal CF sector earning US \$12 million annually. Current research, therefore, aimed partly at the international policy process; with a view to influence to ensure that $\mathrm{CF}$ for sustainability is included in CDM after the first commitment period of Kyoto i.e. after 2012. The research will produce the much required data and technical guidelines for carbon survey at community level but needs further actions at government level to further the advocacy. Initiative from government agencies is crucial to further the international lobby in favour of bringing CF into Kyoto Protocol.

Timely preparation and implementation of national climate change policy is utmost important to save lives and properties but in this respect Nepal has already lagged behind to other South Asian countries as part of fulfilling international commitments, thus, loosing opportunities of securing international funds available to developing countries. For example Nepal has not been able to develop NAPA (National Adaptation Plan of Actions), which is a mandatory document for UNFCCC party nations. Nepal prepared and submitted the first 'National Communication Report on Climate Change' to UN in 2004, but follow up activities of the report are still pending resulting in poor representation of Nepal's priority agendas in the international policy processes. Identifying specific climate change related problems and their 
implications to health, environment, economy and development processes are the basis for further planning.

\section{Conclusion}

Though the debates over climate change have shifted from gathering evidences whether climate change is happening to how to cope with it, there is no good news to developing countries like Nepal as rich countries are still locking horns over sharing costs for implementing measures to mitigate the impacts. How to cope with the imminent threat of climate change is the new focus of the global discourse. Obviously empowering communities with information, technological skills, education and employment is the answer for the question, but this is difficult for the resource poor developing countries like Nepal.

Some of the services also can be bundled up for making payable to local community. For example, community forests generate not only timber, medicinal plants, fuel, fodder, and grass but also supply fresh water, provide habitat to wildlife and sequestrate carbon among others. Out of these environmental services, carbon sequestration is now payable in international market both under clean development mechanism of Kyoto Protocol and voluntary market promoted by agencies willing to contribute to the nature. Building awareness level and enabling activities for capacity building at national to local level is crucial not to miss the opportunity of tying global policy with local conservation and development activities through global climate funds.

Though generating and sharing of area specific climate change related information may come as a top priority agenda, ensuring proper use of information in planning and implementing policy processes is even more important. Such information is vital for project planning and development (to enhance resilience capacity of community and development infrastructures), capacity building of national and local institutions and upgrading negotiation skills, planning and implementing innovative research and development schemes. In more specific terms, focused activity aimed at strengthening capacity of people in vulnerable sectors or regions could be effective if made appropriate interventions through dissemination of right information, involving them in mainstreaming activities, and enhancement of resilience power. It is strongly recommended to review and readjustment of plans such as infrastructures development schemes, disaster management and raising awareness level of general public is the key climate change adaptation strategy.

\section{References:}

Dahal, N. 2006: Implications of climate change in Nepal: Some observations and opportunities.. Paper presented at 23 ${ }^{\text {rd }}$ Warden Seminar November 2007 held in Pokhara, Nepal. Department of National Parks and Wildlife Conservation, Kathmandu, Nepal. 
Hannah, L, and Salm, R., 2003: Protected Areas and Climate Change. In Hannah, L and Lovejoy, T.E. (Eds) Climate Change and Biodiversity: Synergistic Impacts. Advances in Applied Biodiversity Science No 4. Centre for Applied Biodiversity, Science. Conservation International. Washington.

MOPE 2001: State of Environment Report of Nepal. Ministry of Population and Environment, Nepal.

MOPE 2004: Initial National Communication Report to the Conference of the parties of the United Nations Framework Convention of Climate Change (UNFCCC). HMGN/ Ministry of Population and Environment. Singhadurbar, Karthmandu.

NTNC, 2006: Final Report of the Project 'Kyoto: Think Global, Act Local' (Third Phase). National Trust for Nature Conservation, Jawalakhel, Lalitpur.

Peters, R.L. 1991: Consequences of global warming for biological diversity. In Wyman, R.L. (ed.) Global Climate Chalnge and Life on Earth. PP. 99-118. New York. Routledge, Chapman and Hall.

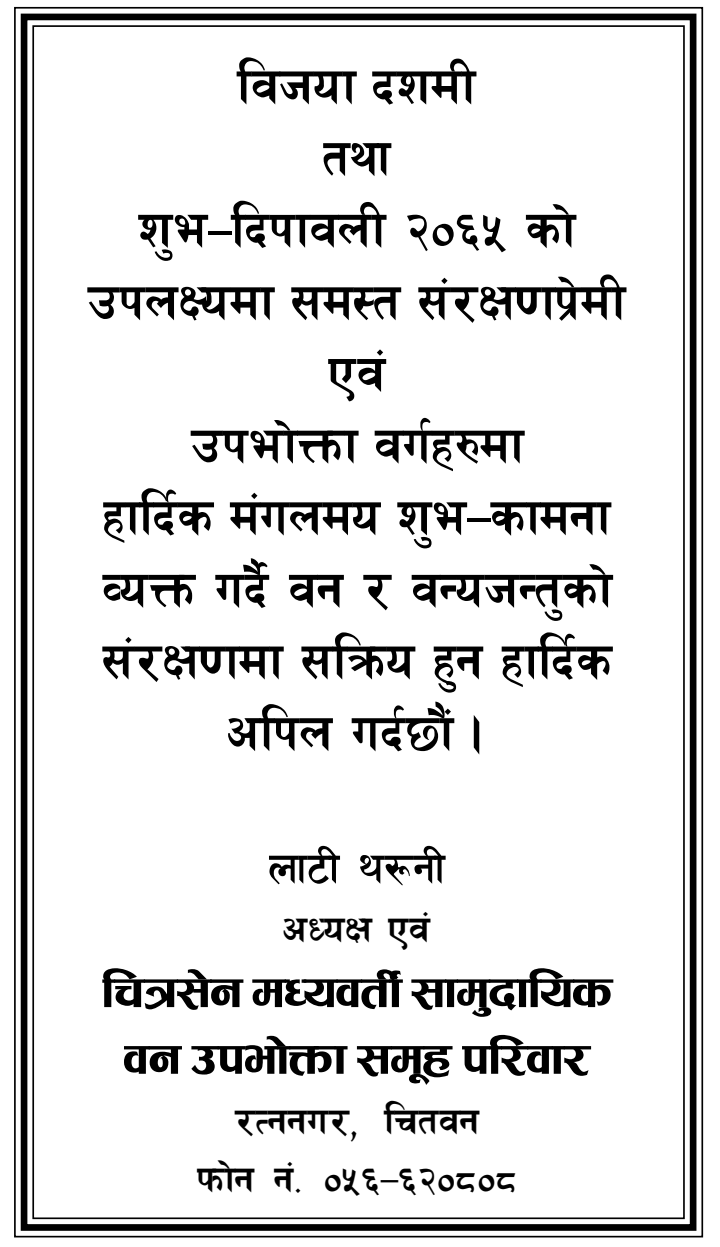

\section{SUFFREC}

\section{विजया दशमी}

तथा

शुभ-दिपावली र०६५ को

पावन अवसरमा

सम्पूर्ण महानुभावहरूमा

हार्दिक मंगलमय शुभ-कामना

व्यत्त गर्दछौं।

व्यवस्थापक : राजु सिलवाल

पुमोरी एग्गोफरेष्टि प्रा.लि.काठमाण्डौ

फोन नं. ०१-४२२०७७३

केन्द्रिय कार्यालय काठमाडौं

मरकनटाइल ग्रुप 